\title{
Bearding the Spaniard: Captain John Oxnam in the Pacific
}

\section{J. S. Dean}

Le capitaine John Oxnam, en 1576-80 était, à prime abord, le premier Anglais à naviguer dans le Pacifique; le premier, avec Drake (plus tôt, 1572-73), pour enrôler l'aide des noirs renégats cimarrons pour attaquer les Espagnols à Panamá; le premier (1576) Anglais à construire un vaisseau (une pinasse de 45 pieds) en bois américain; et, dans ce vaisseau armé, étaient le premier Anglais à saisir les barques péruviennes, leur or et leur argent. Bien que finalement capturé et exécuté en 1580, six mois durant il avait terrorisé les Espagnols et avait contesté leur autorité en Amérique latine.

In the 1570s, after fifty years of Spanish settlement and commerce, the Pacific backside of her American empire was still largely undefended. Why, asked English seafarers, should there not be an England that looked onto those waters, to Pacific gold, silver, pearls, cochineal, woods, hides, and Oriental silks? First and most obviously, other than via Cape Good Hope, the Pacific was the other way to the riches of the Orient. Second, if an English captain could double Cape Horn, he might just strike it rich by taking an unwary Peruvian treasure ship coasting northwards for Panamá, easy pickings for a heavily armed English vessel, at least for a few years. Third, such raids would be easier if the English had a naval base from which to sail. Fourth, if a base, why not, in the Queen's name, a fully fledged settlement?

Such thoughts of a Pacific England were in the air in the 1570s, long before the first Atlantic colonies. English was being spoken along the Pacific a full decade before Ralegh's abortive Virginia planting in 1585, over thirty years before Jamestown in 1607, and nearly a half-century before Plymouth in 1620. As for permanent Pacific English reconnaissance by sea and land, these efforts began only in the late 1700s, when Captain James Cook sailed the Pacific Northwest in 1778, Captain George Vancouver explored Puget Sound in 1792, and Alexander Mackenzie pressed overland reaching the sea in 1793. Why so long? The only viable route was by sea, by way of Cape Horn, where the prevailing westerlies are often Force 8 (a gale to forty knots) and higher, with currents piling up rogue waves thirty metres high, and treacherous ice reaches as far north as $40^{\circ}$ South latitude.

So much can depend on little things. Were it not for a flurry of chicken feathers, a beautiful dueña, and a pork barbecue, England might well have raised her flag on Pacific 


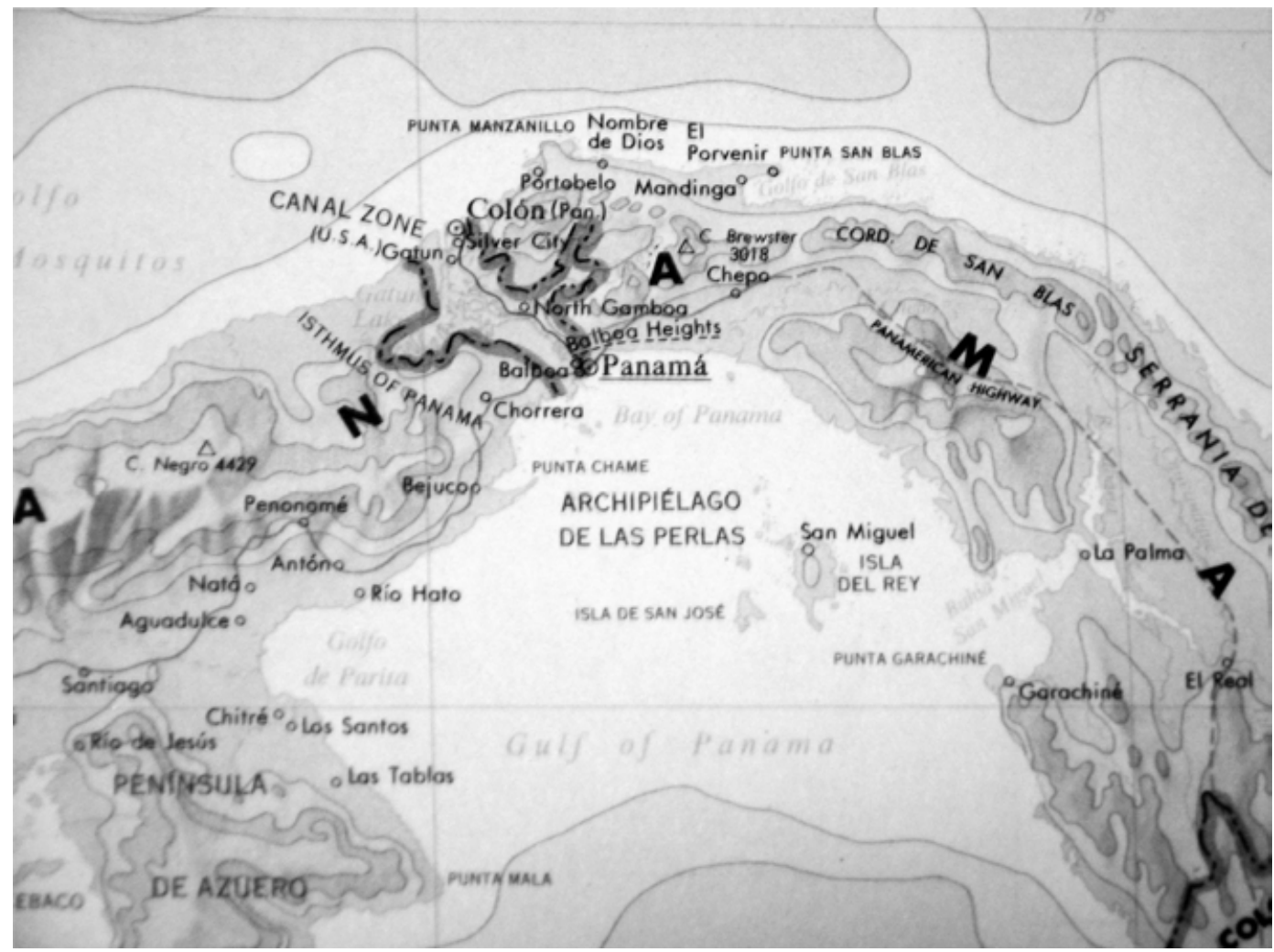

Illustration 1: Panamá, from Caribbean Sea, INT 402. Nautical chart. (Washington, 1979).

shores in the 1570s rather than in the 1790s. The estimates are that in the 1570s there were only some 150,000 Spanish in the Americas, spread thin across the two continents. The Spanish rightly felt their hegemony threatened when the English appeared. The first four Pacific navigations by English seafarers to challenge the Spanish in Pacific waters were Sir Francis Drake and Captain John Oxnam in the 1570s, Sir Thomas Cavendish in the 1580s, and Sir Richard Hawkyns in the 1590 s. $^{1}$ Consider here arguably the first of

1 This article constitutes a part of a larger work I am undertaking on Elizabethan seafarers in the Caribbean and on the Spanish Main. The essential historiography on Oxnam has been done by James A. Williamson, The Age of Drake (1938; repr., Cleveland, 1965), who devotes a short chapter (pp. 133-144) to Oxnam; and Harry Kelsey, Sir Francis Drake: The Queen's Pirate (New Haven,1998). Others treating Oxnam are John Masefield, On the Spanish Main, or, Some English Forays on the Isthmus of Darien (London,1906); EBook 19396 (28 Sept. 2006); David F. Marley, Wars of the Americas: A Chronology of Armed Conflict in the New World 1492 to the Present (Santa Barbara,1998). See also the lively fictional account by historian Charles Kingsley, Westward Ho! (Cambridge, 1855).

The essential primary sources are found in Richard Hakluyt, ed. Principal Navigations. . 1598-1600 [PN], 12 vols. (Glasgow, 1903-1905); Samuel Purchas, ed. Hakluytus Posthumus, or Purchas His Pilgrimes. . . 1625 [PP], 20 vols. (Glasgow, 19051907). Portuguese and Spanish details of Oxnam's voyage are given in Hakluyt by Lopez 
these men to navigate the Pacific: Captain John Oxnam (Oxenham), the first Englishman, along with Drake, to enlist Black renegades and challenge Spain's control of Panamá, the first Englishman to build a pinnace from American wood, and the first Englishman to sail the Pacific and to seize Peruvian ships, their gold, silver, and pearls. His story, here told as chronicle history, covers the years 1576-80.

\section{April 1576. Oxnam sails from Plymouth for Panamá.}

As a trusted lieutenant, Oxnam had taken part in Drake's raid on the Spanish Main in 1572-73. At one point the Cimaroons (renegade Blacks) had helped Oxnam and Drake climb to the top of a hill in the San Blas Mountains, and up a tall tree. Perched there, the English could see the waters of the Pacific off to the south. Both vowed someday to sail those waters. It was Oxnam, before Drake, who was the first to navigate the South Sea. Several accounts, English, Spanish, and Portuguese, tell the story of this extraordinary Plymouth mariner, ${ }^{2}$ a near exact contemporary (four years older) than his

Vaz, written 1586 from the River Plate, $P N$, 10:77-81, and by Irene A. Wright, ed., Documents concerning English voyages to the Spanish main, 1569-1580 [DE] (London, 1932). Wright uses as exemplar Hakluyt, and includes Sir Francis Drake Revived and Andrew Barqueer's 1576 voyage to the West Indies, $D E$, ix, xlii, xlviii, and Doc. 29, $327 \mathrm{ff}$. Wright also prints in $D E, 339$ ff. Sir Richard Hawkyns' account of Oxnam's voyage, found in Hawkyns' telling of his equally unsuccessful 1593 voyage to the Pacific.

See also Kenneth R. Andrews, Drake's Voyages (London, 1967); Harry Kelsey, Sir John Hawkins: Queen Elizabeth's Slave Trader (New Haven, 2003); James A. Williamson, Sir John Hawkins: The Time and the Man (Oxford, 1927), Hawkins of Plymouth, 2nd ed. (London, 1969); David B. Quinn and A. N. Ryan, England's Sea Empire, 1550-1642 (London, 1983); Samuel Eliot Morison, The European Discovery of America: The Southern Voyages (London and New York, 1974); and J. H. Parry, The Age of Reconnaissance (Berkeley, 1963) and his Discovery of the Sea (Berkeley, 1981).

2 James A. Williamson, Irene A. Wright, Kenneth Andrews, Harry Kelsey, and J. H. Parry are generally better anchored in fact than some others. For instance, some historians have Oxnam setting out from Plymouth in 1574,1575 , or 1576 , all on the same voyage. The year 1575 is erroneously given as Oxnam's death date by The Dictionary of National Biography (London, 1964) rather than 1580, as later historians cite it. Spanish and English $16^{\text {th }}$ century accounts of course differ, as the two countries were then at war. The English versions of Oxnam and Drake's voyages are often sparse and thin, or as in Drake Revived, 1626, the year the Duke of Buckingham was impeached and Charles I became king, we find a version reproving a country seen by some as lacking effective leadership. The Spanish sources are often more reliable, written in America within days or months of the events. Moreover, biographers and historians often have different ends, and will reach different conclusions. Caveat lector.

In this article, as multiple sources for an incident are often treated together, for clarity, citations are given at the start of a passage. For the ease of the reader, Tudor and Stuart texts have been modernised. Dates from early English documents are here given in Old Style (Julian Calendar), and Spanish and Portuguese ones in New Style (Gregorian) which in this period moves the Spanish dates ten days on from the English. The English did not adopt the NS calendar until 1752, when it also made 1 January the start of the new year. Until then both 1 January and 25 March (Lady Day, the Feast of the Annunciation of the Blessed Virgin, 
friend Drake.

Oxnam set out from Plymouth on 9 April 1576 for Panamá as owner and captain of an eleven-gun frigate, 100-140 tonnes, name unknown, carrying two knocked down pinnaces, and a crew of fifty-seven (fifty by some accounts). Oxnam, then about forty, was a gentleman of "grave demeanour, much feared and respected and obeyed by his soldiers." He came from an established Devon family, and like Drake, was known to be a "bold sailor and fiery sea-captain," a man of "courage and ability," of "rude courage" but unfortunately he was "without fact or discretion," and "excited the ill-will of his own men." He reached Panamá in the rainy season of late summer 1576, hid his frigate along the coast, and with his two pinnaces, took a Spanish frigate (possibly two prizes) and eighteen prisoners. He recovered his own frigate, and sailed his vessels and the prizes to the Golfo de Acla, hiding them on Piños Island north of Acla. For two weeks Oxnam was on the mainland at Ronconcholon, where he re-established relations he and Drake had made three years earlier with the Cimaroons hiding out from their Spanish masters in the bush. In their hatred against the Spanish, the Cimaroons were most happy to help the English cross the peninsula to reach the Pacific. All they asked in return were to be given any Negro and Spanish prisoners, the latter, to be eaten. Meanwhile, the Audiencia in Panamá, under its president, the conscientious but contentious Dr. Gabriel de Loarte, on hearing of Oxnam's arrival, ordered out a frigate and a brigantine manned by twenty soldiers from Nombre de Dios to capture Oxnam.

\section{August 1576. Spanish find English frigate, Oxnam and crew escape in pinnaces.}

The Spanish found Oxnam's frigate (and the Spanish one), freed the Spanish prisoners, took Oxnam's cannon, supplies, and the linen he intended for trade. Oxnam's crew of forty left to guard the ships escaped, and was able to salvage one vessel's hardware, cordage, and sails, before burning her. Now with just the two pinnaces, Oxnam and his men sailed to an inlet (or creek) near Acla, a small coastal village deserted by the Spanish since 1532, buried what ordnance and stores they had left, opened the seacocks and sank the pinnaces to keep them safe until their return from the Pacific. The mission was a daring one, no less than to build another pinnace and raid the Pacific coast. When asked later why he was there, Oxnam ${ }^{4}$ was to testify that he had come to Vallano to barter cloths, hatchets, machetes, and other merchandise for the gold and silver of the Cimaroons. The Spanish, he said, had seized twenty harquebuses which were ashore, but he and his men had saved another twenty. From the frigate the Spanish had taken swords and weapons. Thus, said Oxnam, he and his men were "disarmed and discomfited." Oxnam testified that he had agreed with the Cimaroons that he would burn the frigate and give the Cimaroons the nails and other metal from it, and kill any Spaniards they captured, in exchange for their help in getting him to the Pacific and its gold and silver. He said that he had hidden his two launches along the river, and that during the winter of

close to the vernal equinox, 20 or 21 March) were variously observed as the start of the year.

3 Williamson, The Age of Drake, 133-44; Dictionary of National Biography, s.v. "Oxenham."

4 DE, 169-77. 
1576 the Cimaroons guided him across the mountains, a narrow twenty leagues from sea to sea, and helped him build another pinnace. That August, as the Spanish took Oxnam's frigate, another Englishman, Andrew Barker set out in the Ragged Staffe and the Bear for the Caribbean on a voyage of reprisal for injuries suffered in the Canaries at Tenerife. He was later to figure in Oxnam's fortunes.

\section{Winter 1576. Oxnam builds first English warship to sail Pacific waters.}

With the help of the Cimaroons, Oxnam crossed the Isthmus of Panamá's twenty leagues ( 1 league, approximately 3 sea miles/1' latitude, approximately 1 sea mile,) to the Pacific. It is only six or seven leagues across the Cordilleras (San Blas) mountain range. The remaining thirteen or fourteen are by navigable rivers. That winter, at the head of the Rio Chucunaque (Rio Indios) the English and the Cimaroons built a 45 -foot (by the keel), twenty-four (twenty) oared sailing pinnace. This vessel was as far as is known the first English vessel to be built and sailed on the Pacific coast, though Balboa had set the example some sixty years earlier when he transported two knocked down brigantines (then rowed vessels) across the mountains of the isthmus, put them together, and explored the Pacific coast.

The Portuguese pilot, Lopez Vaz,

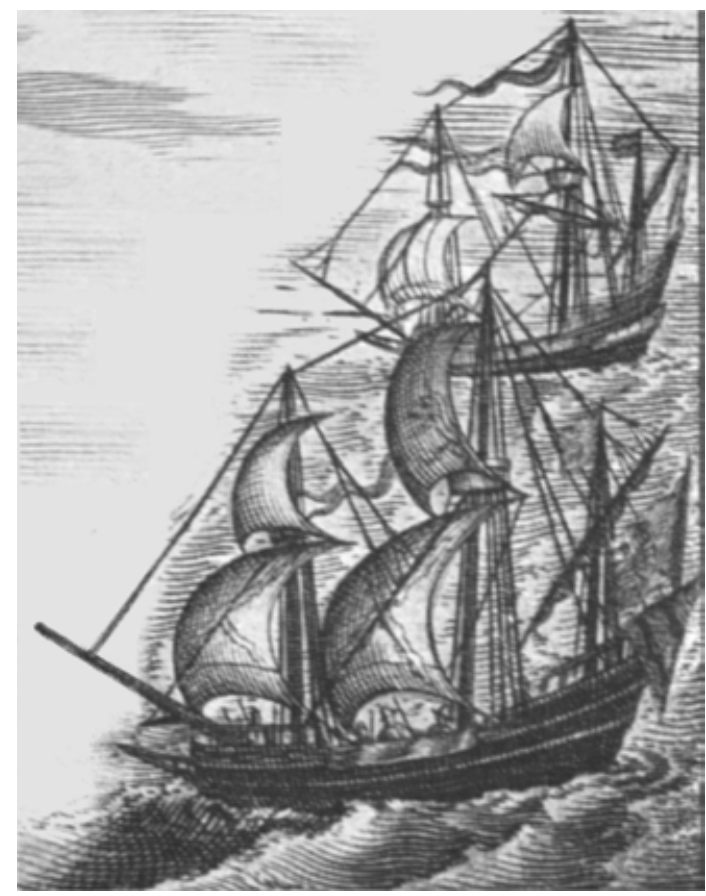

Illustration 2: Contemporary engraving of pinnaces from from Visscher's series (circa 1588, Claes Jansz Visscher, 1534-1593). Detail from a 1901 print; courtesy Archives and Collections Society.

has a somewhat different twist on Oxnam's story, one that conflates events in the 1576-80 story. "This man," Vaz writes,

covered his ship after he had brought her aground with boughs of trees, and hid his great ordnance in the ground, and so not leaving any man in his ship, he took two small pieces of ordnance, and his calivers, and good store of victuals, and so went with the negroes about twelve leagues into the main land, to a river that goeth to the South sea, and there he cut wood and made a pinnace, which was five and forty foot by the keel. And having made this pinnace, he went into the South sea, carrying six negroes with him to be his guides, and so went to the Island of Pearls. 
Vaz calls Oxnam's vessel a pinnace, as does Oxnam. Spanish authorities variously called her a galliot, a barque, a galley, a launch, or shallop, names often interchanged by Spanish and English writers. Pinnaces, often used as advice boats, were usually some twenty tonnes displacement, square-rigged on the fore and mainmasts, and fore-and-aft rigged with three or four jibs, a fore-staysail, and a lateen mizzensail. Oxnam's pinnace had twelve (ten) oars to a side and drew less than half a foot of water, according to Spanish accounts.

Sir Richard Hawkyns, later captured in 1593 by the Spanish off Cabo San Francisco, a short sail south of Panamá, picks up Oxnam's story in $1576 .{ }^{6}$ Hawkyns notes that the Cimaroons were eager to help the English, as long as they could have any prisoners, to "feed their insatiable revenges, [as they were] accustomed to roast and eat the hearts of all those Spaniards, whom at any time they could lay hand upon." Such was their great hatred of the Spanish, observes Hawkyns.

Oxnam, his English crew, and the Cimaroons launched the pinnace in the upper reaches of the Rio Chucunaque (the River Maize). Running down the Chucunaque and then the Rio Tuira, the pinnace, armed with two fast-loading cannon and manned by fifty ${ }^{7}$ English with calivers and some ten (six) Cimaroons, entered the Golfo de San Miguel in late January 1577. He then sailed into the Golfo de Panamá and to the Archipelago de las Perlas (Pearl Islands). He reached Las Perlas on Ash Wednesday, 20 February, that day of penance, an irony not lost on Spanish officials ${ }^{8}$ at Nombre de Dios who wrote on 17 April: "Because of the sins which we who live in this land have committed, God permitted to befall what we have so long foreseen, and English corsairs allied with the cimarrones have crossed to the Pacific. . . where they did great damage in carrying off the negroes and negresses they found there."

For ten days Oxnam lay hidden among the islands, just twenty-five leagues from Panamá, until a small barque (then a small sailing vessel) from Guayaquil (Quito) appeared from the south. Her cargo included 60,000 pesos of gold, and, writes Vaz, ${ }^{9}$ "much wine and bread." Six days later another barque brought him a further 100,000 pesos in silver bars.

Hawkyns has a spicier account of seizing that Peruvian barque from Guayaquil (Quito). ${ }^{10}$ He notes that from her Oxnam had taken two pieces of special value. One was a "table of massie gold, with emeralds, sent for a present to the King; the other a Lady of singular beauty, married, and a mother of children. The latter grew to be his perdition," writes Hawkyns. The lady, not surprisingly, is not mentioned by Vaz; nor do any of the Spanish accounts mention her. "John Oxman (I say) was taken with the love of this Lady," writes Hawkyns, "and to win her good will, what through her tears and

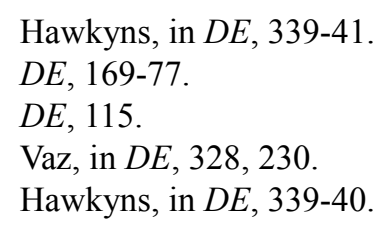


persuasions, and what through fear and detestation of their barbarous inclinations, breaking promise with the Symarons, yielded to her request, which was to give the prisoners liberty with their ships, for that they were not useful for him. Notwithstanding Oxman kept the Lady, who had in one of the restored ships, either a son or a nephew." Once freed, this young man with others made straight for Panamá to warn the authorities.

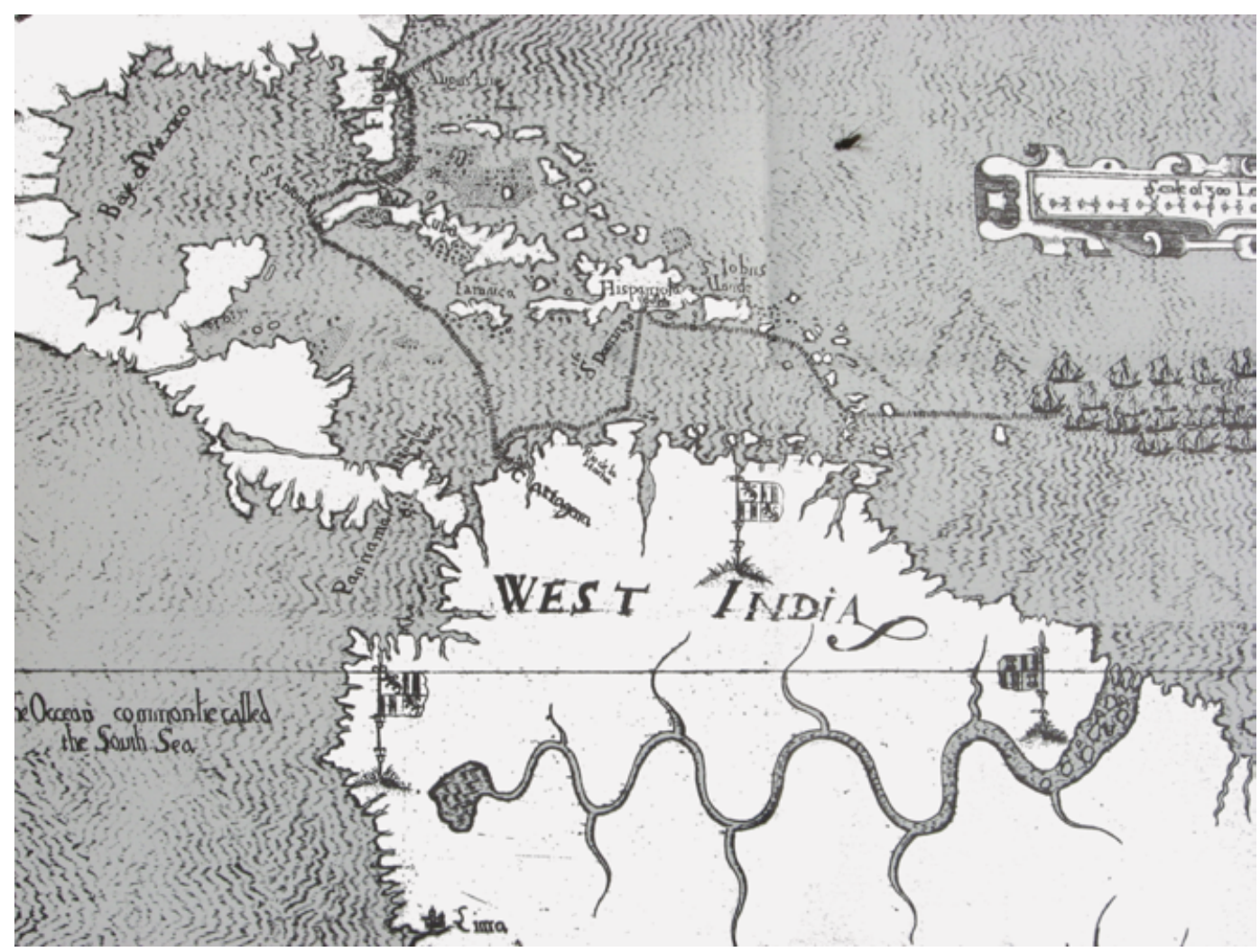

Illustration 3: West India, and Panamá. Map of Drake's West Indian Expedition, A.D. 15851586. In Richard Hakluyt, Principal Navigations. . . 1598-1600, vol. 10, end pocket illustrations.

At this point Oxnam had outdone his former commander, Drake, the feared "El Draque" on several accounts. He had built an armed pinnace from native wood deep in Panamá's jungles, was the first to sail that pinnace on the Pacific, and with her was now the first to seize Spanish vessels in those waters. The 160,000 pesos topped the treasure that he and Drake had taken in the botched 1572-73 raid on the mule trains in Panamá four years earlier. In 1577 it was not Drake but Oxnam who was the real and the present danger for the Spanish, as he terrorised Spanish America in a mere 45-foot pinnace armed with two cannon. High in confidence, the next week Oxnam pillaged and plundered the archipelago for pearls and further loot, and desecrated anything Papist. His mission's outcome exceeded the wildest hopes. All that remained was to get the treasure back across to the Caribbean, and return with it to England, and there enjoy great glory, laud, and honour. 


\section{March 1577. Oxnam undone by chicken feathers and a "lady of singular beauty."}

With his small pinnace heavily ballasted with gold, silver, pearls, the Spanish dueña and prisoners, Oxnam sailed from Las Perlas back to the Golfo de San Miguel and the Rio Tuira, intending to return with lady and loot up the Rio Chucunaque and across the Cordillera to the Caribbean and then home. But rashly he set the Spanish barques, their crews, and the Pearl Islanders free. These quickly alerted the authorities of the enemy pinnace in their Pacific waters.

Within hours of their arrival, Loarte and the Audiencia at Panamá ordered Pedro de Ortega Valencia to take 200 men (of the 500 soldiers garrisoned there) in six vessels to hunt down and capture Oxnam, the loot, and, no doubt, to bring back the lady. At Las Perlas Valencia learned that Oxnam had sailed for the Rio Tuira in the Golfo de San Miguel. Valencia set off in hot pursuit after the lone pinnace. "The pursuers, approaching the river, were doubtful by which of the afore-remembered three mouths they should take their way," writes Hawkyns. "In this wavering one of the soldiers espied certain feathers, of hens and some boughs of trees (which they had cut off to make their way) swimming down one of the outlets." Here were the clues they needed. The Spanish frigates entered the Rio Tuira, and for eight days made their way upstream, until it became too shallow to navigate. A watch was left aboard. Sixty men marched day and night for four days along the the banks of the Rio Chucunaque. At ten in the morning of 2 April, as they reached the head of the river (near the confluence of either the Rio Tupisca or Rio Chico), the Spanish came upon thirty English and eighty Cimaroons "making good cheer in their tents and divided in two partialities about the partition and sharing of their gold and silver. Thus were they surprised, and not one escaped," writes Hawkyns. On that particular morning Oxnam was a few leagues away, seeing the loot across the San Blas mountains to the Caribbean. But the next day Valencia caught up with Oxnam. Oxnam was wounded, but escaped along with twenty others into the bush. Three days later, Oxnam and his men counterattacked, but were forced to withdraw with heavy casualties, barely escaping capture by the Spanish.

$\mathrm{Vaz}^{12}$ recounts that the Spanish put their prisoners aboard the English pinnace, and returned to Panamá. "So the voyage of that English man did not prosper with him, as he thought it would have done," moralises Vaz. Torture revealed that the English planned to return to England and come back with 2,000 men to settle with the Cimaroons and "infest the Pacific."

In its report to the Crown, the City Council of Panamá ${ }^{13}$ corroborates Hawkyns' account. Captain Pedro de Ortega Valencia, by "Divine touch" had noticed chicken feathers floating down one branch of the river. For eight days he had tracked the English, and at last he "found the trail of the English, who had left pork and biscuits, which they carried, on the river bank where they stopped to eat." After four days, at ten on Tuesday

\footnotetext{
11 Hawkyns, in DE, 340-41.

12 Vaz, in $D E, 328-33$.

$13 \quad D E, 132-35$.
} 
morning of Holy Week, he saw some thirty English and more than eighty Cimaroons cooking "a quantity of pork in kettles and amusing themselves together. They had a canvas awning stretched, where they were unloading the biscuit and everything else they had in the launch. Being of light draft (drawing little over a palm of water) it had been able to navigate so far up."

Valencia attacked at once, killing over twenty-five English and many Cimaroons. The officials said to the Crown: "We certify to your majesty that Pedro Menéndez did not merit more recognition, nor do as much in killing Jean Ribaut and all his company in Florida, as Pedro de Ortega Valencia has done in defeating and capturing John Oxnam. . . For had Oxnam succeeded in his undertaking, it would have entailed the total ruin of this realm and the utmost damage and disturbance through all Peru." To the Spanish authorities in Panamá an English attack on the peninsula was far more dangerous than any threat from the French (or English) in Florida.

\section{June 1577. An open road from Atlantic to Pacific for English.}

On 7 June, the City of Panamá ${ }^{14}$ reported to Viceroy Don Francisco de Toledo in Perú that in "the war on the Lutheran English and the cimarrones" Captain Melo and his forty men had recently found Oxnam's two pinnaces (launches) "half submerged in an inlet, hidden under certain trees." The next day, 8 June, Dr. Loarte ${ }^{15}$ wrote in his own name from Panamá to the viceroy that there were just twenty English still uncaptured, but these "were left unarmed - having not a knife, not a weapon, not a harquebus, bow nor arrows - and without subsistence, tar, cordage, nails or tools." No threat there. The viceroy thought otherwise. In short order he sent his own commander, General Diego de Frias Trejo, to stamp out the English.

On 28 July Trejo ${ }^{16}$ reported from Panamá to the Crown that the president of the Audiencia, Dr. Loarte, would not receive him. Loarte claimed his authority outranked that of the viceroy, and would not even supply subsistence for Trejo's men. "I can not carry a sufficient supply with me, for lack of slaves. The President will not support me, I fear, judging by the little assistance he has given me thus far."

Under torture, Cimaroons confessed that Peter Canoa (possibly Canoba) and some dozen (nine) men had escaped to sea, but, said the Cimaroons, these English had all drowned. In their canoe, the English had in fact not drowned, but had captured a barque at Tolú and set out for England, promising to return with legions of English to drive out the Spanish. This news of Canoa and his men turns out to be the last we hear of them. Were they in fact lost at sea? Meanwhile, eighteen prisoners were taken to Panamá and tried. Thirteen were promptly hanged. Two of the boys were sent to Spain for Catholic indoctrination. Three were clapped in irons.

In the end, says Vaz, the Cimaroons betrayed the English. Hawkyns ${ }^{17}$ was years

\footnotetext{
14 DE, 144-48.

15 DE, 149-52.

16 DE, 154-57.

17 Hawkyns, in $D E, 330,341$.
} 
later to note that the Cimaroons had turned Oxnam and the other survivors over to the Spanish because Oxnam had broken his promise to let them roast and eat the Spanish prisoners' hearts. "At the trial, the Justice of Panamá asked the English captain [Oxnam] whether he had the Queen's licence, or the licence of any other Prince or Lord for his attempt. And he answered he had none, whereupon he and all his company were condemned to die, and so were all executed, saving the Captain, the Master, the Pilot, and five boys which were carried to Lima."

Hawkyns, after his own capture by the Spanish fifteen years later, moralises:

This may be a good example to others in like occasions: first, to shun such notorious sins, which cannot escape punishment in this life, nor in the life to come: for the breach of faith is reputed amongst the greatest faults which a man can commit. Secondly, not to abuse another man's wife; much less to force her, both being odious to God and man. Thirdly to beware of mutinies, which seldom or never are seen to come to better ends; for where such trees flourish, the fruit of force must either be bitter, sweet, or very sour. And therefore, seeing we vaunt our selves to be Christians and make profession of his law, who forbideth all such vanities, let us faithfully shun them, that we may partake the end of that hope which our profession teacheth and promiseth.

As for Oxnam's "lady of singular beauty?" Her dark attractions, her fortunes, her fate-all these remain a mystery lost deep in the Panamanian jungle.

\section{September 1577. "Surrender Dog!” Oxnam captured in banana grove.}

Finally, nearly nine months after the English raids in Las Perlas in February, on 8 September Oxnam was tracked down and taken in a banana grove with seven (or nine) other English in the Vallano region near the Rio Banique. On 12 July 1578, ten months after Oxnam's capture, the Audiencia ${ }^{18}$ in Panamá took the prisoner's deposition (just five days after Drake had beheaded a mutinous Thomas Doughtie on 7 July 1578 at Port Julian, prior to transiting the Strait). The royal notary and clerk, Juan Lorenzo Perez, writes: "The Englishman said that his name was John Oxnam, English by birth, forty-two years old, and that he was the captain of the English who crossed this ocean, and that he is a Christian and has been baptized." Oxnam's deposition gives details of his capture on 8 September 1577.

Oxnam and four other Englishmen were in a banana grove in Vallano when they learned of a party advancing through the bush. He had been aware that the Spanish (campmaster Pedro Arana and his men) were pursuing them. Earlier, Oxnam had seen them, and realised they had seen him too. "He fled, seeking to hide behind a cabuya or bejuco tree, but could not reach it. While so endeavouring, he looked and saw a soldier, whom they call Gonzalo, and a negro. Gonzalo was armed with a sword and shield, and the negro with a bow and arrows. Deponent gripped a lance and advanced on the soldier and on the negro, and they gave back." Oxnam sought cover. When he saw Don Gomez de Rojas' match lighted on the serpentine, his harquebus aimed and ready to fire, Oxnam 
threw up his hands and cried out to Rojas, "For the love of God, don't kill me!" Rojas ordered Oxnam to drop his lance. Rojas, the Negro, and others seized Oxnam, cuffed him, and wounded his head many times with a knife.

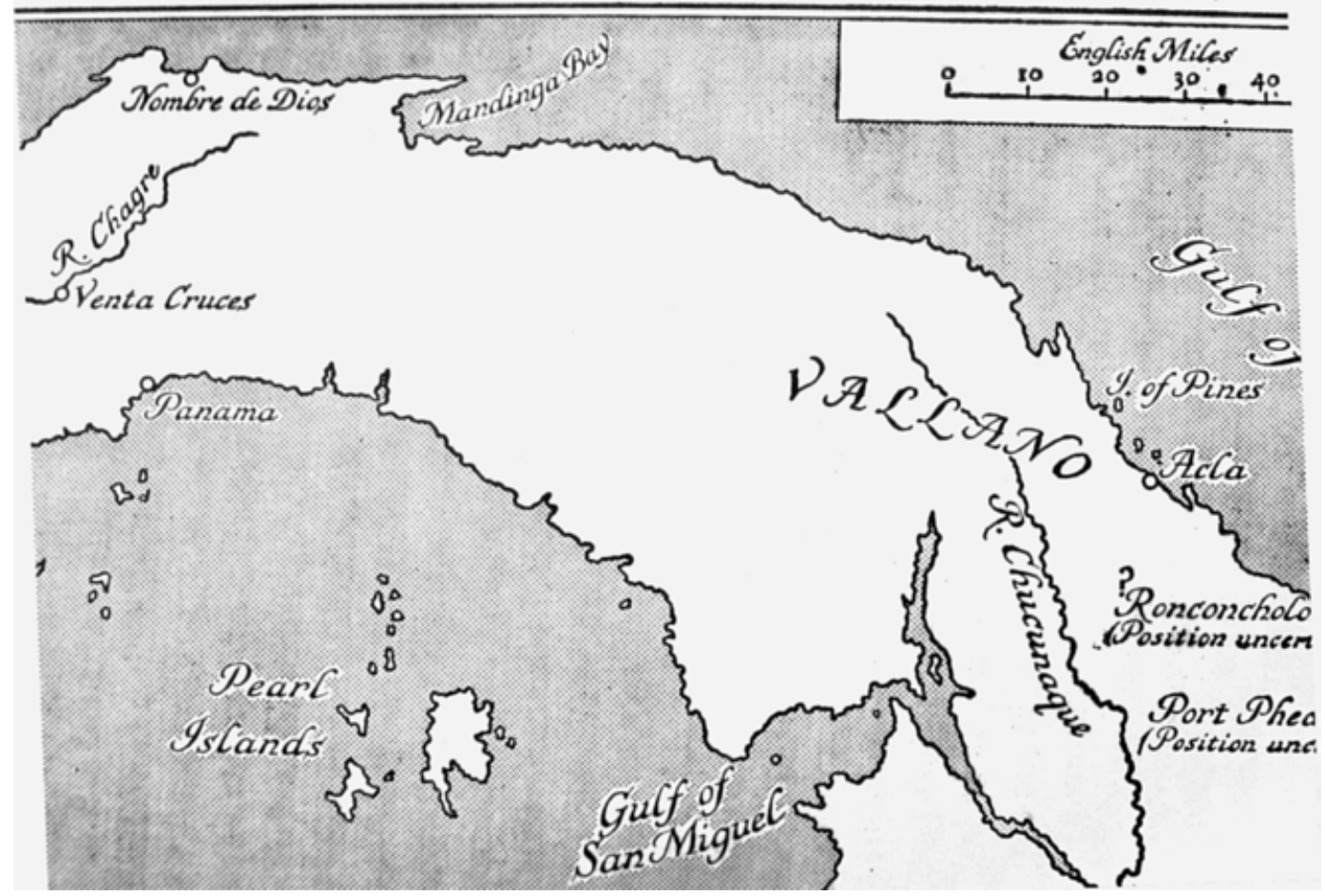

Illustration 4: Panamá, 1572-73. James A. Williamson, The Age of Drake, 120.

\section{November 1577. Drake's fleet leaves Plymouth for South sea.}

Meanwhile, as the raid and the hunt for Oxnam and his men was playing itself out in Panamá, a new chapter in English maritime history was getting under way in England. Oxnam's former captain, Sir Francis Drake, was marshalling his fleet for the South sea. Drake's admiral was the Pelican (120 tonnes), later known as the Golden Hinde, and Captain John Wynter's Elizabeth was vice-admiral. Drake's was not a large fleet, neither in number or tonnage - two ships, one barque, a flyboat, and a pinnace - in all totalling about 300 tonnes, less than half that of the Jesus of Lubeck (700 tonnes), Sir John Hawkyns' admiral lost to the Spanish nine years earlier at San Juan de Ullua in 1568. Drake's fleet cleared Plymouth on 15 November. Drake reached the Pacific ten months later in September 1578. After disease, hostile Indians, treason, and storms, his fleet was reduced to just one vessel, the 120 tonne Pelican. In her Drake made his way north along the Pacific coast. Leave him for the present sailing along the Chilean coast, and return back to the winter of 1577, with Oxnam's crew still in the wilds of Panamá's jungles. 
What of the manhunt for the remaining English still in the bush? On 18 February 1578, five months after Oxnam's capture, General Trejo ${ }^{19}$ wrote from San Miguel de Vallano to the Crown that on 7 December 1577 he had come onto six English in a canoe, paddling upstream, intending to cross the peninsula to reach the Caribbean and to escape. Trejo fell upon them at night, capturing five of the English. "One of them is the most important man among all who came over, because he is the most astute and sagacious of them all, and acted as their pilot and interpreter. He is a very clever pilot, and speaks Spanish and other languages well; they call him Chalona [John Butler, the nickname in Spanish, one who slackens, lets down], and by this name he is well known and famous."

In March, Drake's fleet was near the Equator, on course for the Strait of Magellan. On 13 March, Don Pedro Fernandez de Busto ${ }^{20}$ wrote from Cartagena to the Crown about a third encounter with the English and the Cimaroons, in which they "killed a number of negroes and captured alive five more English and twenty blacks, among these a negress whom that nation considered its queen. She revealed certain secrets concerning the country, and the villages of the other nations, and told where the other English are. Some nineteen of them are still at large."

Less than three weeks after de Busto wrote to the Crown, Drake's five vessels had crossed the Atlantic in a fast fifty-four day passage, reaching Brazil at about three in the afternoon of 5 April. ${ }^{21}$ He sailed on south-southwest, and anchored in the River Plate on 14 April, and put to sea again on 27 April, course south-southwest towards the Strait of Magellan. ${ }^{22}$

\section{May 1578. Arana: 300 English could control Panamá.}

On 21 May 1578, Pedro de Arana, ${ }^{23}$ a veteran soldier of thirty-eight years' service in Europe and South America, wrote from Panamá to the Crown summarising the Vallano War, the name now given to the mopping up operation against Oxnam and his men. Viceroy Toledo believed that it was essential to stop the English. He commissioned Diego de Frias Trejo (General Trejo), his equerry, who had served him earlier in campaigns waged against the Inca and the Chiriguanaes, to be campmaster and commissary-general. As funds were scarce, the viceroy also commissioned Don Diego de Mora, "a rich young man, son of a deceased resident of the city of Trujillo," to be admiral of the fleet. Toledo further raised a force of 145 soldiers by "forcibly requestioning sixty half-breeds, mulattoes and negroes to serve them," and shipped them off in two large vessels. Hardly seasoned soldiers, these. He ordered that two of the pearlfishing barques at Manta, on the Puerto Viejo coast, be taken and converted to brigantines that could be rowed into coastal inlets and up rivers, or if at sea, could assist ships in battle.

Arana feared that Dr. Loarte had some "private interest of his own" for ordering the return of the forces to Panamá, and suspected that Loarte was trying to take over the forces himself in order to get all the credit for expelling and killing the English. The Royal High Court in Panamá nevertheless gave Arana forty more soldiers and some Negro carriers. Arana sailed

\footnotetext{
$19 D E, 200-02$.

$20 \quad D E, 207$.

$21 \quad P N, 11: 153$.

$22 \quad P N, 11: 105-08$.

23 DE, 223-31.
} 
for the Vallano region. There he caught the English captain, seven other English sailors, and five Negroes. Interrogation revealed that Peter Canoa (Canoba), a gentleman, had quarrelled with the English captain (Oxnam) about whether to re-embarque on the Indios River, and continue the pillage, or to march straight away across to the Atlantic, construct rafts and sail to Tolú, capture a barque, conclude their mission, and sail home. The English had split up, Oxnam went one way, Canoa (Canoba) another. Canoa and his men had built a canoe (rafts, according to the Audiencia) and embarqued on the Caribbean Sea. Arana reported that he had captured "Chalona an Englishman [John Butler], a very important person, and four others with him.” The hunt was over. The victory was Spain's. Spanish colonials had stopped the English infidels, the "Lutheran heretics."

Meanwhile, in early July Drake's fleet was nearing the Strait, coasting along within a harquebus shot of land. Hakluyt records that the sailors could see giant Indians, ${ }^{24}$ one of whom cried out "Magallanes, Esta he minha Terra, that is Magallanes, this is my countrey." Such was the Indian hatred of their Spanish conquerors. On 21 August (24 August according to Drake's kidnapped Portuguese pilot, Silva) the winds turned favourable, and Drake could enter the Strait of Magellan. There by the ancient custom of "turf and twig" he claimed the Strait for England. ${ }^{25}$ Treasure yes, but also turf and twig. Loot first, but land followed.

On 6 September his fleet reached the Pacific. There, storms separated the vessels, and on 1 November Drake started up the Pacific coast of South America alone, with just one vessel, the Pelican. On 13 February 1579 the Pelican anchored in Callao (12 South latitude), the port for Lima. When the Pelican entered the harbour, she was boarded by Spanish inspectors. Shocked and stunned on seeing her armament, the officials jumped back in their launch, and rowed for shore, shouting "Frenchmen." The English were not expected. Drake sent the pinnace to search the harbour for two ships supposedly carrying silver, but could not find them. The pinnace cut the cables on the eight or nine ships anchored in the harbour, hoping to exchange them as bargaining chips for ransom.

For from the Spanish prisoners, Drake had learned that his old friend Captain John Oxnam, as well as Ship's Master Thomas Sherwell and John and Henry Butler were imprisoned nearby in Lima, less than two hours' march away. But with only some thirty English fit to fight at this point, Drake, could hardly storm Lima. Sacking Cartagena in 1585 and Cádiz in 1587 came later. His, not the Spaniard's beard, would have been badly singed in Lima. Drake thought briefly that he might barter the eight or nine ships whose cables he had cut for his friends' lives. But instead of drifting out to sea, the vessels had drifted ashore. Meanwhile, Drake, who had been earnestly seeking news of a treasure ship, finally heard that the ship of San Juan de Antón, heavily laden to her lines with treasure, had only recently left Lima, bound for Panamá. Drake ordered the Pelican and the pinnace to weigh anchor immediately and make sail in hot pursuit.

\section{October 1580. A Lima Prison.}

It is no small irony that Oxnam was in chains in a Lima prison on 13 February 1579, the date that his former captain Drake had sailed into Callao in the Pelican, only three leagues

$24 \quad P N, 11: 135$.
$25 \quad P P, 2: 129$.


away. But the Pelican, though bristling eighteen cannon and the most powerful warship in the Pacific, had only thirty men fit to fight. Drake was powerless against the viceroy in Lima.

As further irony would have it, not long after Oxnam's capture three years earlier, in 1577, Captain Andrew Barker had been raiding the Spanish Main, and had seized a Spaniard's ordnance. Four of those cannon were reported ${ }^{26}$ to have been part of Oxnam's original eleven. Though Barker, after mutiny, was soon to be killed by the Spanish elsewhere in the Caribbean, his ship was reported to have brought the four cannon back to England, leaving them in the Scilly Isles.

In a final twist, less than three weeks after Drake's visit to Callao, he was off Cabo de San Francisco, at $1^{\circ}$ North latitude, the same headland which Oxnam had doubled only months before, on his way to prison in Lima. Near the cape, on the evening of 1 March 1578, Drake, was clearing for action. He was about to engage San Juan de Antón's Nuestra Señora de la Concepción, better known by her nickname, Cacafuego (Shitfire). She was soon taken. Her treasure? Eighty pounds of gold, thirteen chests of coin, 1,300 bars of silver, and a further fourteen chests with more coin and gold. 362,000 pesos of registered gold and silver, and another 40,000 pesos unregistered. There was so much additional silver that Drake threw the Pelican's stone ballast into the sea and replaced it with silver. Seven months later, Oxnam's fellow West Countryman Drake was to bring his heavily laden Pelican into Plymouth Harbour (some say Portsmouth) on 26 September 1580 (a few date the return as in October or November). Drake and his Pelican entered history as the first captain and his ship to circumnavigate the earth (Magellan had died enroute). His riches bought him his knighthood, Buckland Abbey, and the Queen's lasting gratitude.

As for his Devon friend and lieutenant, Captain John Oxnam and the three others? To the Spanish, these Protestants were clearly pirates and heretics. Left there in Lima, the Inquisition was at pains to convert these "Lutheran heretics" to Catholicism. Once converted, their penance for heresy was to be chained in the galleys for life. Viceroy Toledo, however, had other ideas. He condemned John Oxnam, John Butler, his younger brother, Henry, and the ship's master, Thomas Sherwell, to death as pirates. The younger Butler was sentenced to a life in the galleys. In October 1580, as winter was giving way to summer in Perú, just days after Drake sailed into Plymouth harbour, the other fiery Plymouth captain and two of his men were executed. The remains of Oxnam, John Butler, and Sherwell lie unmarked, somewhere in Peruvian soil. What happened to young Henry Butler, condemned to Spanish galleys for life, we do not know.

Captain Oxnam remains, as far as we know, the first Englishman to build a vessel from American timbers, the first to sail that pinnace as the first English warship on the Pacific, and the first to seize a treasure in Spanish gold and silver in those waters. Ashore, Oxnam was the first to lead legions of Spanish soldiers on a chase for a full half year through the Panamanian jungle, thus offering the first sustained English challenge to Spanish rule in America. 